\title{
Major Aspects of the Mercury Cycle in the Negro River Basin, Amazon
}

\section{Gilmar Silvério da Silva, ${ }^{a}$ Márcia Cristina Bisinoti, ${ }^{b}$ Pedro Sérgio Fadini, ${ }^{c}$ Gabriela Magarelli, ${ }^{d}$ Wilson F. Jardim*,e and Anne Hélène Fostier ${ }^{e}$}

\author{
${ }^{a}$ Instituto Federal de Educação, Ciência e Tecnologia do Maranhão, Departamento Acadêmico de Química, \\ 65025-000 São Luís-MA, Brazil \\ "Instituto de Biociências, Letras e Ciências Exatas, Universidade Estadual Paulista "Júlio de Mesquita Filho", \\ 15054-000 São José do Rio Preto-SP, Brazil \\ 'Departamento de Química, Universidade Federal de São Carlos, CP 676, 13565-905 São Carlos-SP, Brazil \\ ${ }^{d}$ Empresa Brasileira de Pesquisa Agropecuária, Embrapa Recursos Genéticos e Biotecnologia, \\ Núcleo de Segurança Biológica, CP 02372, 70770-900 Brasilia-DF, Brazil
}

eInstituto de Química, Universidade Estadual de Campinas, CP 6154, 13083-970 Campinas-SP, Brazil

\begin{abstract}
Embora com pouca atividade humana, as concentrações de Hg na bacia do Rio Negro são relativamente altas. A presença natural de $\mathrm{Hg}$ em solos e a deposição atmosférica são as principais fontes deste metal. O balanço entre fluxos invasivos e evasivos sugerem o seu acúmulo no interior da bacia em $39.9 \mathrm{t}^{\text {ano }}{ }^{-1}$. O tipo de solo, fonte de metal para os rios, e o ciclo hidrológico com períodos de cheia e seca atuam sobre a química redox das águas. A conjunção sazonal de fatores como a natureza da matéria orgânica, $\mathrm{pH}$ ácido e radiação solar permitem que as águas pretas oscilem de redutora a oxidante, onde, por sua vez, ocorre o consumo de $\mathrm{Hg}^{0}$ e degradação do metilmercúrio. Deste modo, o fluxo do mercúrio pode ser invasivo ou evasivo. Embora a metilação seja mais favorecida em águas pretas, a fotodegradação do metilmercúrio se contrapõe ao seu acúmulo, contribuindo para regular o estoque deste composto na coluna água.
\end{abstract}

Despite the low level of industrial activity and human density, $\mathrm{Hg}$ concentration in the Negro River basin is relatively high. Soil enriched with naturally high $\mathrm{Hg}$ concentrations and atmospheric deposition are the main sources of the metal in this watershed. Differences between invasive and evasive fluxes at the water/air and soil/air interfaces indicate $\mathrm{Hg}$ accumulation in the basin at a rate of $39.9 \mathrm{t} \mathrm{y}^{-1}$. The type of soil, which is the main source of mercury for the water bodies, the hydrological cycle with floods and dry periods, act markedly on the water redox chemistry. A complex interaction between many seasonable variables such as solar intensity, water $\mathrm{pH}$, age of the naturally occurring organic matter and the hydrological cycle alter the redox characteristics of these black water bodies, thus markedly affecting the consumption of $\mathrm{Hg}^{0}$ and the degradation of methylmercury present in the water. Although methylation is favored in black waters, photodegradation counterpoints this formation, thus regulating the methylmercury burden in the water column.

Keywords: Negro River, mercury fluxes, mercury species, black waters

\section{Introduction}

Mercury contamination in the Amazon basin became a matter of world concern when high levels of mercury were detected in fish from the Madeira river. ${ }^{1}$ After this episode, several research groups, ${ }^{2-16}$ have investigated this topic in different areas in the Amazon, in order to understand the

*e-mail: wfjardim@iqm.unicamp.br sources and fate of mercury. In the Negro river basin high mercury concentrations were found in soils (average value of $\left.170 \mu \mathrm{g} \mathrm{kg}^{-1}\right)^{3-8}$ and in other matrices, although the median concentration in the atmosphere was relatively low, on the order of $1.3 \mathrm{ng} \mathrm{m}^{-3} \cdot{ }^{17-19}$ Different from other regions in the Amazon, this basin has little gold-mining activity and there are many indications that naturally occurring mercury leaching from soil $(99.7 \%)$ is the major pathway to mercury enrichment of the aquatic environment. ${ }^{8}$ 
Mercury and its related redox species show a complex cycle in the environment. ${ }^{12,16,20-23} \mathrm{In}$ a broad aspect, $\mathrm{Hg}^{2+}$, methyl mercury $(\mathrm{MeHg})$ and dissolved gaseous mercury (DGM), which is almost totally $\mathrm{Hg}^{0}$, are the main species found, and their capacity for interconversion is responsible for the mercury dynamics. Mercury in soil is naturally present in rocks, although other sources of mercury inputs to forest ecosystems are associated with dry and wet atmospheric deposition..$^{24}$ Forest canopies are effective in trapping atmospheric mercury due to a high adsorption surface area for interception. ${ }^{24-26}$ Because transfer of $\mathrm{Hg}$ from soil to leaves through roots is usually negligible, mercury present in vegetation can be considered as a result of atmospheric deposition. ${ }^{27,28}$ Although some mercury compounds that accumulate on foliage are washed off by precipitation, thus increasing its concentration in soil, many studies suggest that litterfall deposition and subsequent decomposition can be considered the main sources of $\mathrm{Hg}$ in soil. ${ }^{24,29-31}$ This mechanism of mercury transfer has been poorly studied in the Amazon forest.

Mercury shows a complex biogeochemical cycle in water bodies, with rates of volatilization controlled by both biotic and abiotic factors. The $\mathrm{Hg}^{0}$ concentration, the main chemical species of the DGM fraction, will determine the evasion/ invasion of the metal in the water column. When $\mathrm{Hg}^{2+}$ is present in the water column methylation can occur, leading to possible bioaccumulation and biomagnification. In the Negro River region, as a result of this process, fish and the riparian population show high mercury levels when compared to populations living close to white water rivers. ${ }^{8,916}$
A broad project on the mercury cycle in the Negro river basin has been undertaken by our laboratories over a period of ten years in order to evaluate mercury concentrations in different compartments (air, water, soil, sediments, fish and humans) and from different mercury sources, trying to assess the soil function in the mercury cycle and to understand the factors that govern invasive and evasive fluxes in the air/water and air/soil interfaces. Our major contribution is to present the mercury budget in this area, based upon data collected during these last ten years, together with some new experiments, and to discuss factors affecting the mercury cycle in the Negro River basin, with emphasis on the organic matter, solar radiation, hydrogen peroxide formation, seasonality and soil function.

\section{Experimental}

\section{Study area}

The Negro River basin spreads over an area of $690,000 \mathrm{~km}^{2}$, which represents $14 \%$ of the total area of the Brazilian Amazon, where the Negro river flows for approximately $1700 \mathrm{~km}$ (Figure 1). ${ }^{32}$ According to Sioli, ${ }^{33,34}$ Amazon tributaries are classified as black water, white water and intermediate water rivers. Black water rivers such as the Negro river drain highly weathered sandy soils of the central Amazon basin, show low sediment and nutrient concentrations, blackish-colored waters rich in dissolved humic substances and acidic $\mathrm{pH}$. White water bodies such as the Branco, Solimões and the Madeira river originate

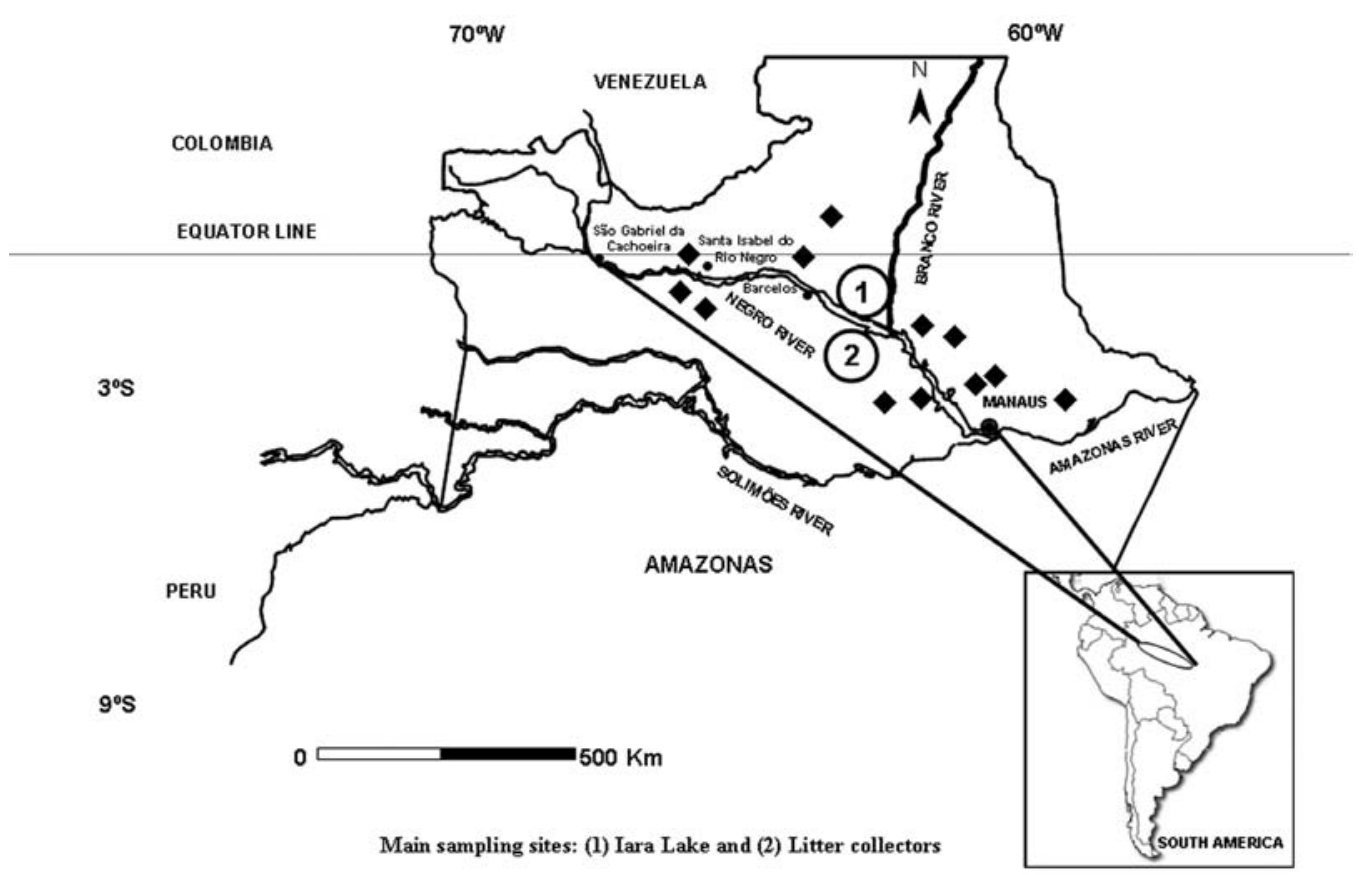

Figure 1. Negro River basin region and sampling point locations. Iara Lake (1), Litter collectors (2), and the main sampling sites ( $\bullet$ ). 
in the Andes and are characterized by a high suspended sediment load, neutral to slightly acidic $\mathrm{pH}$, low organic matter concentration (below $9 \mathrm{mg} \mathrm{C} \mathrm{L}^{-1}$ ) and are rich in dissolved nutrients due to rapid weathering in piedmont regions. Intermediate water bodies present characteristics between black and white waters.

The Negro River basin is characterized by two distinct hydrological seasons: the dry period (September to February) and the wet period (rainy season from March to August), where the water level difference can reach up to $15 \mathrm{~m}$. In the rainy season, rivers tend to flood, covering the forest and surrounding areas, forming the so-called "igapós", which act as an important source of labile organic carbon to the water bodies, thus markedly affecting both the major nutrient cycles and the mercury chemistry. ${ }^{3,8}$

\section{Sampling periods and stations}

From 1994 to 2004, several samples of different matrices were colleted and characterized along the Negro River basin and its tributaries (Figure 1) in dry (January) and wet (July) periods. Mercury concentrations, including its major species, and matrix characteristics along the basin can be found elsewhere for soil, ${ }^{8}$ black and white waters, ${ }^{8,35}$ sediment, ${ }^{8}$ atmosphere, ${ }^{8,18,35}$ rain water, ${ }^{8,35}$ and fish. ${ }^{36}$.

\section{Mercury inputs in the Negro river basin}

Wet deposition over the Negro river basin has been estimated by combining analytical data obtained from total $\mathrm{Hg}$ measurements in rain water with hydrographic and pluviometric maps using Remote Sensoring (RS) and GIS (Geographic Information System) tools. The same tools were used to estimate total flux at the water/atmosphere interface..$^{35}$

Mercury inputs via litterfall were calculated from total mercury concentration in litterfall samples and from litterfall deposition measured in a forest plot (Figure 1). Four $1 \mathrm{~m}^{2}$ litterfall nylon traps were installed in a $c a .1$ ha plot at $20 \mathrm{~cm}$ above ground level. The litterfall (leaves only) was sampled monthly from January to December 2003. Samples were oven-dried at $60{ }^{\circ} \mathrm{C}$ for a $24 \mathrm{~h}$ period and weighed.

\section{Cleaning and sampling procedures}

All precautions were taken in order to avoid contamination during sampling. The labware were placed in a $\mathrm{HCl}$ :water $(1: 4 \mathrm{v} / \mathrm{v})$ bath for $48 \mathrm{~h}$ at $80^{\circ} \mathrm{C}$ on a hot plate ${ }^{37}$ For water collection, bottles of polyethylene terephthalate (PET) commercialized for mineral water were used according to the recommendations of Fadini and Jardim. ${ }^{38}$ The bottles were washed several times at the sampling site and filled $30 \mathrm{~cm}$ below the surface. For both total and reactive mercury analysis, water samples were collected and preserved for transportation to the laboratory. Water samples for organic mercury analysis were extracted using methylene choride and stored in a refrigerator for transportation. ${ }^{37}$

\section{Analytical procedures}

Total and reactive mercury in surface water, ${ }^{8}$ bulk precipitation, ${ }^{8,35}$ and the atmosphere, ${ }^{8,35}$ were quantified using double-stage gold amalgamation followed by cold vapor atomic fluorescence spectrometry (CVAFS from Brooks Rand ${ }^{\circledR}$ model 2). Organic mercury was determined after solvent extraction following a published procedure. ${ }^{16}$ DGM was determined ${ }^{35}$ by purging surface water using argon and the analytical curve was constructed by injections of known concentrations of $\mathrm{Hg}$ saturated air. ${ }^{39}$ The air/ water fluxes were estimated using Fick`s law and Henry`s constant. ${ }^{35}$ Total $\mathrm{Hg}$ in leaves was determined after wet digestion of ground samples at $75{ }^{\circ} \mathrm{C}$ with a mixture of concentrated $\mathrm{HNO}_{3}$ and $30 \% \mathrm{v} / \mathrm{v} \mathrm{H}_{2} \mathrm{O}_{2}$, by cold vapor atomic absorption spectrometry (CVAAS, Buck ScientificMercury Analyser Vapor 400-A). Analytical accuracy was checked using standard reference materials ${ }^{\circledast}(\mathrm{SRM})$ from the National Institute of Standard and Technology (NIST): SRM-1515 Apple leaves; error was less than $11 \%$ and triplicate analyses showed an analytical precision $<10 \%$.

Microcosm experiments to evaluate the effects of hydrogen peroxide, organic matter and solar radiation on organic mercury dynamic

Water samples were collected in PET bottles without headspace and spiked with methyl mercury to a final concentration of $55 \mathrm{ng} \mathrm{L}^{-1}$, a concentration not far from natural conditions yet measurable with confidence in the field. The bottles were maintained submerged near the top of the surface water $(30 \mathrm{~cm}$ below the surface) so that they could receive solar radiation and be maintained at the same temperature as the river. Three water samples from each group were wrapped with aluminum foil to act as dark controls. After $0,2,4$ and $6 \mathrm{~h}$ of solar radiation, samples were collected and analyzed for organic mercury, gaseous dissolved mercury and hydrogen peroxide. The experiments were performed from 11 am to $5 \mathrm{pm}$ and the solar radiation intensity was monitored at $365 \mathrm{~nm}$. A control group containing ultrapure water (MilliQ) spiked with methyl mercury at the same concentration was kept in the same conditions. A parallel experiment was set using 
catalase $\left(1000 \mathrm{nmol} \mathrm{L}^{-1}\right)$ to keep the hydrogen peroxide concentration below $20 \mathrm{nmol} \mathrm{L}^{-1}$.

\section{Results and Discussion}

\section{Soil and soil cover roles in the mercury cycle}

In this watershed, soil acts not only as a sink of atmospheric $\mathrm{Hg}$ depositions and a long-term source of mercury, but also plays an important role in the redox water chemistry of the Negro river. ${ }^{8}$ Mercury wet deposition reached values between 17 and $27 \mu \mathrm{g} \mathrm{m}^{-2} \mathrm{y}^{-1}$, averaging $22.9 \mu \mathrm{g} \mathrm{m}^{-2} \mathrm{y}^{-1}$, which corresponds to an input of $15.8 \mathrm{t} \mathrm{y}^{-1}$ over the whole basin. ${ }^{35}$ Litterfall deposition ranged from $41 \mathrm{~g} \mathrm{~m}^{-2}$ month $^{-1}$ (April) to $133 \mathrm{~g} \mathrm{~m}^{-2}$ month $^{-1}$ (November), resulting in $8.4 \mathrm{t} \mathrm{ha}^{-1} \mathrm{yr}^{-1}$. $\mathrm{Hg}$ concentration in litter varied from 35.4 to $61.5 \mathrm{ng} \mathrm{g}^{-1}$ (mean \pm standard deviation: $48 \pm 10 \mathrm{ng} \mathrm{g}^{-1}$ ). By combining litterfall deposition and $\mathrm{Hg}$ concentration, mercury deposition through litterfall varied from 2.4 to $5.2 \mu \mathrm{g} \mathrm{m}^{-2}$ month $^{-1}$, resulting in an estimated transfer of $43 \pm 15 \mu \mathrm{g} \mathrm{m}^{-2} \mathrm{y}^{-1}$. Although data were limited to one area in the basin, it is important to note that litterfall deposition was of the same order as those reported in many other studies in the Amazonian region..$^{30,40,41} \mathrm{The} \mathrm{Hg}$ concentrations in the litter were also on the same order than those reported by Mélières et $a l . .^{30}\left(64 \mathrm{ng} \mathrm{g}^{-1}\right)$ and Roulet $e t$ $a l .{ }^{42}\left(99 \mathrm{ng} \mathrm{g}^{-1}\right)$ for different places in the Amazonian region, and estimated $\mathrm{Hg}$ litterfall deposition was in accordance with the one published by Mélières et al. ${ }^{30}\left(48 \pm 12 \mu \mathrm{g} \mathrm{m}^{-2} \mathrm{y}^{-1}\right)$ for remote areas in the French Guianan forest.

Considering only the non-floodable forest area of the Negro river basin (89\% of the whole basin), $\mathrm{Hg}$ input through litterfall would be $26.7 \mathrm{t} \mathrm{yr}^{-1}$. It is important to note that in the forested areas, throughfall (the rainfall that passes through the canopy and becomes enriched in $\mathrm{Hg}$ because of the wash-off of dry deposited $\mathrm{Hg}$ compounds from the leaf surfaces) can also significantly contribute to $\mathrm{Hg}$ deposition to forest soils. ${ }^{13,26}$ Since the mercury concentrations in throughfall were not measured in the Negro river basin, the sum of wet deposition and litterfall deposition should therefore be a low estimate of the total atmospheric deposition in forest areas.

Magarelli and Fostier ${ }^{18,19}$ also showed the strong influence of deforestation on gaseous mercury fluxes at the air/soil interface. In forested areas, a low emission value $\left(1.3 \pm 1.3 \mathrm{pmol} \mathrm{m}^{-2} \mathrm{~h}^{-1}\right)$ was observed during the day and an equivalent deposition value was observed at night, showing that soils do not act as an atmospheric Hg source in forested areas. Nevertheless, in deforested areas, fluxes were always positive $\left(13.7 \pm 10.3 \mathrm{pmol} \mathrm{m}^{-2} \mathrm{~h}^{-1}\right)$ clearly indicating that $\mathrm{Hg}$ is being emitted to the atmosphere both during the day and at night. Among the factors that control $\mathrm{Hg}$ emission, the soil temperature appeared as one of the strongest influences, mainly in deforested areas where higher solar exposition of the soil results in higher soil temperatures in both periods. ${ }^{18} \mathrm{~A}$ high soil temperature contributes to increasing vapor pressure for the different mercury compounds, especially those species that are highly volatile, such $\mathrm{Hg}^{0}$ and $\left(\mathrm{CH}_{3}\right)_{2} \mathrm{Hg} \cdot{ }^{43}$ The chemical and physical processes that probably control $\mathrm{Hg}$ emission from soil also play an important role in the distribution of different $\mathrm{Hg}$ species among different soil phases, which is largely associated with sorption and desorption of $\mathrm{Hg}^{0}$ and $\mathrm{Hg}^{2+}$ and redox reactions in soils induced by sunlight ${ }^{43}$ and mediated by humic substances. ${ }^{44,45}$

As mentioned, atmospheric mercury input to soil covered by forest can be expected to be significantly higher than in deforested areas, while $\mathrm{Hg}$ emissions are significantly enhanced in deforested areas. Soil coverage is also a determinant parameter in controlling $\mathrm{Hg}$ transfer from soil to aquatic systems because both leaching and soil erosion increase in deforested areas. Working in another Amazonian region, Fostier et al. ${ }^{7}$ showed that $\mathrm{Hg}$ fluxes between terrestrial and aquatic systems were three times higher in deforested areas when compared to the pristine forest area of the same basin. In addition, deforested areas contribute to water body siltation, increasing the mercury stock, since experiments on mercury leaching showed an average leaching capacity of $1.5 \mathrm{mg}$ of mercury per $\mathrm{kg}$ of soil in 14 days of contact with pure water, under laboratory conditions. ${ }^{8}$

In the Negro river basin, studies performed with soil samples from floodable and non-floodable areas show the importance of the soil organic matter in the Hg cycle. ${ }^{45,46} \mathrm{It}$ has been shown that soil organic matter acts as a mercury sink, and that in this type of soil, $\mathrm{Hg}$ (II) sorption is chiefly governed by the organic matter content. ${ }^{30}$ Consequently, in deforested areas where organic matter contents are lower due to intensive leaching, higher amounts of mercury will be desorbed from soils and transferred to the aquatic system. The correlation $\left(r^{2}=0.68\right)$ between total mercury concentration $\left(\mathrm{Hg}_{\text {total }}\right)$ and dissolved organic carbon (DOC) from various rivers of the Negro River basin also corroborates the importance of organic matter in mercury transport from drainage areas to the aquatic system. ${ }^{47}$

\section{Dissolved gaseous mercury (DGM) formation/consumption}

Due to seasonal flooding, which can reach up to $11 \%$ of the total forest area, there is an important input of fresh (labile) organic matter to the water bodies. In a recent work, Bisinoti ${ }^{48}$ has pointed out the importance of the 
hydrological cycle for organic matter turnover in the Negro River basin, which, associated with high solar intensity and low $\mathrm{pH}$, can significantly alter the redox conditions in the water column, especially in the sunlit portion. Both reductive and oxidant conditions vary as a function of organic matter aging in black waters.

In white water bodies, with nearly neutral $\mathrm{pH}$, it has been suggested that photogenerated $\mathrm{H}_{2} \mathrm{O}_{2}$ is able to reduce $\mathrm{Hg}^{2+}$ to $\mathrm{Hg}^{0}\left(\mathrm{H}_{2} \mathrm{O}_{2}+2 \mathrm{OH}^{-}+\mathrm{Hg}^{2+}=\mathrm{O}_{2}+2 \mathrm{H}_{2} \mathrm{O}+\mathrm{Hg}^{0}\right)$. In turn, in black waters, the existence of an oxidative mechanism converting $\mathrm{Hg}^{0}$ to $\mathrm{Hg}^{2+}$ by photogenerated $\mathrm{H}_{2} \mathrm{O}_{2}$ is assumed $\left(\mathrm{H}_{2} \mathrm{O}_{2}+2 \mathrm{H}^{+}+\mathrm{Hg}^{0}=2 \mathrm{H}_{2} \mathrm{O}+\mathrm{Hg}^{2+}\right)^{49}$ as also discussed by other autors. ${ }^{50-52}$ Both redox reactions would involve $\mathrm{H}_{2} \mathrm{O}_{2}$ photogenerated by UV light and dissolved organic matter interactions. ${ }^{53-55}$ Amon and Benner, ${ }^{56}$ working with water samples from the Negro River, verified that $15 \%$ of the dissolved organic carbon stock was composed of photoreactive labile species degradable to $\mathrm{CO}_{2}$ when exposed to sunlight for periods up to $27 \mathrm{~h}$. Recently, Silva et al..$^{49}$ have reemphasized major aspects related to this complex redox water chemistry.

Other natural parameters that are affected by the redox chemistry in the Negro River basin include the $\mathrm{Fe}^{2+} / \mathrm{Fe}^{3}$ redox couple through Fenton-type reactions $\left(\mathrm{H}_{2} \mathrm{O}_{2}+\mathrm{Fe}^{2+}=\right.$ $\cdot \mathrm{OH}+\mathrm{OH}^{-}+\mathrm{Fe}^{3+}$ ), where ${ }^{\bullet} \mathrm{OH}$ radicals are able to oxidize $\mathrm{Hg}^{0}$ to $\mathrm{Hg}^{2+} \cdot{ }^{57}$ Recently, Silva et al. ${ }^{49}$ have discussed this possible oxidative mechanism in the black water of the Negro River basin. Lalonde at al. ${ }^{58}$ have shown the role of semiquinones and chloride in the photooxidation of $\mathrm{Hg}^{0}$ in laboratory experiments. From the studies carried out in the evaluation of mercury flux at the water/air interface, the predominant mechanism observed for black waters is an invasive flux during the day and an evasive flux at night. ${ }^{35,49}$

It is interesting to note that, for white water bodies, the observed trend is the opposite, with invasive flux during the night and evasive flux under sun light with respect to the water phase. This is explained by the presence of photogenerated hydrogen peroxide that favors the reduction of mercury at $\mathrm{pH}$ values near neutrality.

This behavior, although attributed principally to hydrogen peroxide, is not always true. During the periods when fresh and labile organic matter is washed from soils to the water bodies, e.g. the beginning of the flooding season, this load of reactive material will consume hydrogen peroxide, thus reducing $\mathrm{Hg}^{2+}$ to $\mathrm{Hg}^{0}$, even under acidic and sunlit conditions, as shown in Figure 2. These mercury fluxes were estimated over 28 hours, between 9 am the first day and $1 \mathrm{pm}$ on the second day. On both days, atypical high DGM fluxes of $3.19 ; 3.80$ and $1.88 \mathrm{pmol} \mathrm{m}^{-2} \mathrm{~h}^{-1}$ were observed during the sunlight period, at 9:00; 16:00 and 13:00 (second day) respectively.

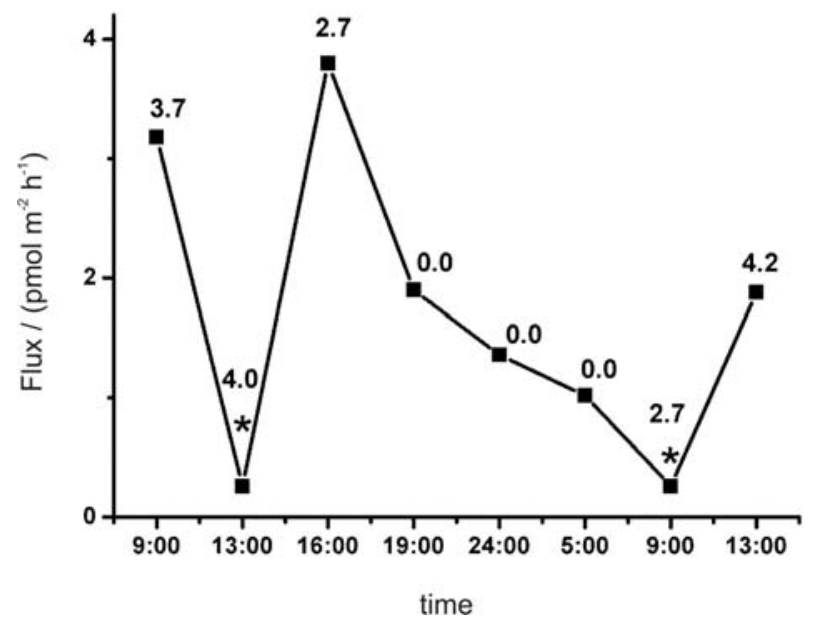

Figure 2. Estimated $\triangle \mathrm{GM}$ flux in the Iara Lake (black water, $\mathrm{pH}$ 3.9; $\left.\Delta \mathrm{OC}=13 \mathrm{mg} \mathrm{C} \mathrm{L}^{-1}\right)$, showing an atypical behavior, with mercury reduction under sunlight. Light intensity values $\left(\mathrm{mW} \mathrm{cm}^{-2}\right.$ measured at $\left.365 \mathrm{~nm}\right)$ are also shown for each value of flux. Measurements carried out in the dry season (February 2001); * represents flux estimated from $\Delta \mathrm{GM}$ values below the detection limit.

\section{Methylation/Demethylation}

Water bodies in the Negro River basin offer propitious conditions for the methylation process, especially at the beginning of the rainy season, due to anaerobic conditions, the presence of labile organic matter and the presence of $\mathrm{Hg}^{2+}$, as shown by Bisinoti and Jardim. ${ }^{16,59}$ However, due to intense solar radiation, a suitable oxidizing condition is observed, as discussed earlier, that initiates the photodestruction of the methyl mercury $(\mathrm{MeHg})$ formed to $\mathrm{Hg}^{2+}$. Sellers et al. ${ }^{60}$ showed that $\mathrm{MeHg}$ could be photodegraded in surface waters via abiotic processes. Solar radiation can be responsible for $\mathrm{MeHg}$ transformation to $\mathrm{Hg}^{2+}$ and $\mathrm{Hg}^{0}$. Similar findings were observed by Siciliano et al. ${ }^{61}$ and Lalonde et al. ${ }^{58}$

Manipulated experiments using black water samples spiked with MeHg and exposed to solar light are shown in Figure 3. As observed, $\mathrm{MeHg}$ is not destroyed in the dark, and $\mathrm{H}_{2} \mathrm{O}_{2}$ seems to play an important role in the destruction of the organic mercurial species as the presence of catalase decreased by half the amount of MeHg destroyed in $6 \mathrm{~h}$ of solar exposure. The principal product of $\mathrm{MeHg}$ destruction is $\mathrm{Hg}^{0}$ (DGM). Similar experiments using different types of Amazonian waters showed the following rates of methyl Hg destruction: black waters $\left(5 \mathrm{ng} \mathrm{L}^{-1} \mathrm{~h}^{-1}\right)>$ white waters (2.8 $\left.\mathrm{ng} \mathrm{L}^{-1} \mathrm{~h}^{-1}\right)>$ ultrapure water $\left(2.5 \mathrm{ng} \mathrm{L}^{-1} \mathrm{~h}^{-1}\right)$. The halflives $\left(\mathrm{t}_{1 / 2}\right)$ for methylmercury photodegradation followed first order kinetics with $\mathrm{t}_{1 / 2}$ of 7 and $4 \mathrm{~h}$ for white and black waters, respectively. ${ }^{48,62}$

In the Negro River basin, $\mathrm{MeHg}$ concentration is lower in white waters $\left(<0.01\right.$ to $\left.0.41 \mathrm{ng} \mathrm{L}^{-1}\right)$ compared to black 


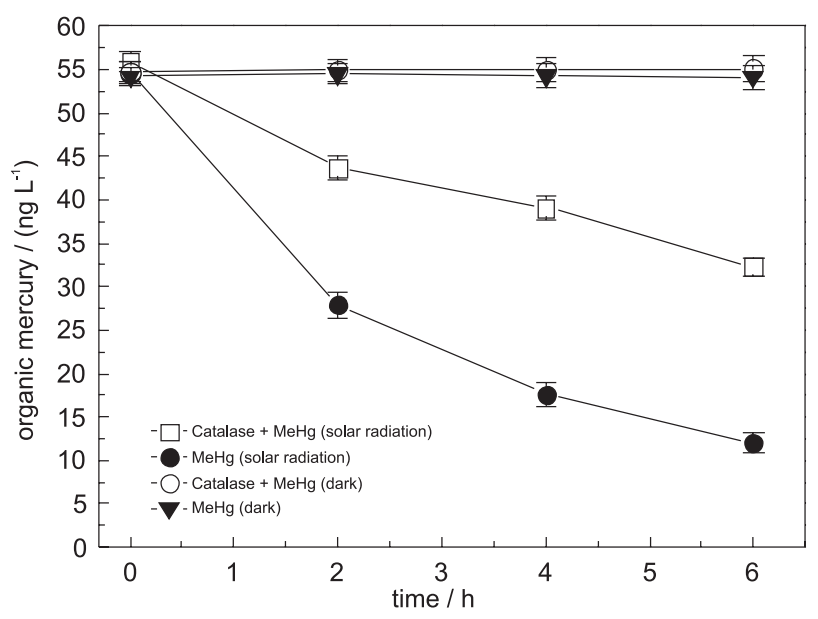

Figure 3. Methyl mercury photodegradation quantified as organic mercury. All water samples were contaminated with $55 \mathrm{ng} \mathrm{L}^{-1} \mathrm{MeHg}$ and exposed to solar radiation.

waters $\left(<0.01\right.$ to $\left.1.63 \mathrm{ng} \mathrm{L}^{-1}\right)$. However, despite the fact that black water bodies present more favorable conditions for methylation, the amount of organic mercurial species is lower than expected, as it is controlled by high rates of photodestruction.

\section{Mercury mass balance in the Negro River basin}

Computing the major sources and sinks of mercury in the Negro River basin over the last 12 years of extensive studies, Figure 4 shows a broad picture of the mercury mass balance in the watershed. Total metal input $\left(42.5 \mathrm{t} \mathrm{y}^{-1}\right)$ is mainly constituted from wet deposition $\left(15.8 \mathrm{t}^{-1}\right)$ and litterfall deposition $\left(26.7 \mathrm{t} \mathrm{y}^{-1}\right)$. Nevertheless it should be emphasized that this value could be underestimated because throughfall deposition has not been estimated, whereas litterfall deposition was calculated only for the nonfloodable forest areas. Total output accounts for $2.61 \mathrm{t} \mathrm{y}^{-1}$, i.e., the sum of fluvial transport $\left(2.2 \mathrm{t}^{-1}\right),{ }^{8}$ evasive flux at

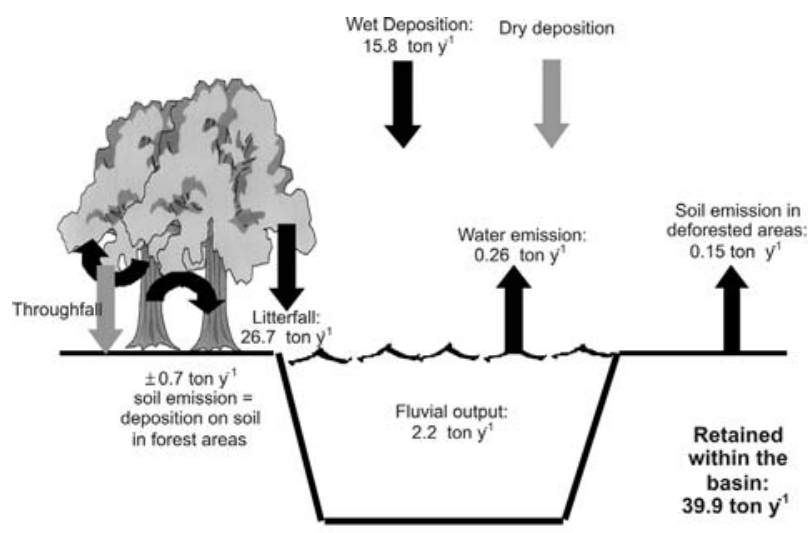

Figure 4. Mercury mass balance in the Negro River basin, Amazon. Grey arrows indicate unestimated fluxes of atmospheric dry deposition and throughfall deposition. the water/atmosphere interface $\left(0.26 \mathrm{ty}^{-1}\right)^{35}$ and deforested area $\left(0.15 \mathrm{t} \mathrm{y}^{-1}\right) .{ }^{18}$ Fluvial transport represents mercury flux from the drainage basin, including all chemical and physical species from flooded or non-flooded areas. In the forested areas, equal diurnal emission and nocturnal deposition rates at the soil/air interface result in no net $\mathrm{Hg}$ emission to the atmosphere. Assuming these average fluxes, the accumulation rate into the Negro River basin is $39.9 \mathrm{t} \mathrm{yr}^{-1}$.

\section{Conclusions}

A long-term study of mercury in one of the most pristine watersheds in the Amazon has shown that, in this naturally enriched metal area, mercury output transport mechanisms are less than the mercury inputs, which leads to an accumulative process into the basin. Although the model adopted is this work is simplified, it clearly shows that the soil in the Negro River basin acts as a sink of mercury, and long-term source of mercury to the water bodies. Mercury concentration in the water column was positively correlated with dissolved organic carbon (DOC), indicating metalorganic-bound species, especially involving humic and fulvic substances, which are the main form transported from watershed to aquatic systems through runoff. ${ }^{63}$

In reaching white and black waters, mercury from terrestrial sources finds different redox conditions that vary according to the hydrological cycle and soil type in the drainage area. Black waters, with acid $\mathrm{pH}$ and high DOC level, and facing a dry period with no input of fresh labile organic matter from soil, creates a natural sunlit oxidative barrier that avoids DGM formation (thus mercury export), and degrades part of the methylmercury formed. On the other hand, although propitiating better conditions for methylation, which ultimately would be translated into bioaccumulation and biomagnification, a seasonal destructive redox barrier is responsible for regulating the methylmercury concentration in this system.

Finally, it has been shown that the mercury cycle in the Negro River basin is clearly associated not only to the hydrological regime, but also regulated by sun light, the availability of organic matter, the $\mathrm{pH}$ and many other secondary substances and by-products (such as $\mathrm{H}_{2} \mathrm{O}_{2}$ ), demanding a great deal of integrated research in order to elucidate the fate and the associated risks of mercury in the area.

\section{Acknowledgments}

The authors would like to thank Prof. C. H. Collins for revising the manuscript. This work was supported by FAPESP (02/03395-1; 00/13517-1). 


\section{References}

1. Martinelli, L. A.; Ferreira, J. R.; Forsberg, B. R.; Victoria, L. R.; Ambio 1988, 17, 252.

2. Malm, O.; Environ. Res. 1998, 77, 73.

3. Silva-Forsberg, M. C.; Forsberg, B. R.; Zeidemann, V. K.; Ambio 1999, 28, 519.

4. Guimarães, J. R.; Fostier, A. H.; Forti, M. C.; Melfi, J. A.; Kehrig, H.; Mauro, J. B. M.; Malm, O.; Krug, J. F.; Ambio 1999, 28, 296.

5. Rocha, J. C.; Sargentini Jr., E.; Zara, L. F.; Rosa, A. H.; Santos, A.; Burba, P.; Talanta 2000, 53, 551.

6. Lechler, J. M.; Lacerda, L. D.; Lyons, W. B.; Bonzongo, J.; Sci. Total Environ. 2000, 260, 173.

7. Fostier, A. H.; Forti, M. C.; Guimarães, J. R. D.; Melfi, A. J.; Boulet, R.; Espirito Santo, C. M.; Krug, F. J.; Sci. Total Environ. 2000, 260, 201.

8. Fadini, P. S.; Jardim, W. F.; Sci. Total Environ. 2001, 275, 71.

9. Barbosa, A. C.; Jardim, W. F.; Dorea, J. G.; Forsberg, B. R.; Souza, J.; Arch. Environ. Contam. Toxicol. 2001, 40, 439.

10. Cordeiro, R. C.; Turcq, B.; Ribeiro, M. G.; Lacerda, L. D.; Sifeddine, A.; Turcq, P. F. M.; Sci. Total Environ. 2002, 293, 247.

11. Barbosa, A. C.; Souza, J.; Dorea, J.G.; Jardim, W. F.; Fadini, P. S.; Arch. Environ. Contam. Toxicol. 2003, 45, 235.

12. Bisinoti, M. C.; Jardim, W. F.; J. Braz. Chem. Soc. 2003, 14, 244.

13. Lacerda, L. D.; Riveiro, M. G.; Souza, M.; Environ. Pollut. 2004, 129, 247.

14. Miretzky, P.; Bisinoti, M. C.; Jardim, W. F.; Rocha, J. C.; Quim. Nova 2005, 28, 438.

15. Bastos, W. R.; Gomes, J. P. O.; Almeida, R.; Oliveira, R. C.; Nascimento, E. L.; Bernardi, J. V. E.; Lacerda, L. D.; Silveira, E. G.; Pfeiffer, W. C.; Sci. Total Environ. 2006, 368, 344.

16. Bisinoti, M. C.; Jardim, W. F.; Quim. Nova 2004, 27, 593.

17. Almeida, M. D.; Lacerda, L. D.; Bastos, W. R.; Hermann, J. C.; Environ. Pollut. 2005, 137, 179.

18. Magarelli, M.; Fostier, A. H.; Atmos. Environ. 2005, 39, 7518.

19. Magarelli, M; Fostier, A. H. Quim. Nova 2005, 28, 968.

20. Amyot, M.; Gill, G. A.; Morel, F. M. M.; Environ. Sci. Technol. 1997, 31, 3606.

21. Amouroux, D.; Wasserman, J. C, Tessier, E.; Donard, O. F. X.; Environ. Sci. Technol. 1999, 33, 3048.

22. Lalonde, J. D.; Amyot, M.; Kraepiel, A. M. L.; Morel, F. M. M.; Environ. Sci. Technol. 2001, 35, 1367.

23. Brigham, M. E.; Wentz, D. A.; Aiken, G. R.; Krabbenhoft, D. P.; Environ. Sci. Technol. 2009, 43, 2725.

24. Grigal, D. F.; J. Environ. Qual. 2003, 32, 393.

25. Munthe, J.; Lee Y.; Hultberg, H.; Iverfeldt, A.; Borg, G. C.; Anderson, B. I. In Experimental Reversal of Acid Rain Effects: the Gardsjon Roof Project; Hulberg, H.; Skeffington, R., eds.; Wiley: New York, 1998, pp. 261-276.
26. Rea, A. W.; Lindberg, S. E.; Keeler, G. J.; Environ. Sci. Technol. 2000, 34, 2418.

27. Rea, A. W.; Lindberg, S. E.; Scherbatskoy, T.; Keeler, G. J.; Water, Air, Soil Pollut. 2002, 133, 49.

28. Ericksen, J. A.; Gustin, M. S.; Sci. Total Environ. 2004, 324, 271.

29. Fostier, A. H.; Cecon, K.; Forti, M. C.; J. Phys. IV France 2003, 491.

30. Mélières, M-A.; Pourchet, M.; Charles-Dominique, P.; Gaucher, P.; Sci. Total Environ. 2003, 311, 261.

31. Silva-Filho, E. V.; Machado, W.; Oliveira, R. R.; Sella, S. M.; Lacerda, L. D.; Chemosphere 2006, 65, 2477.

32. Instituto Brasileiro de Geografia e Estatística, Amazônia Brasileira; Geography Edition National Council of X Congresso Brasileiro de Geografia, RJ, Brasil, September, 1944.

33. Sioli, H.; Am. J. Trop. Med. Hyg. 1953, 2, 700.

34. Sioli, H. In Amazônia: Fundamentos da Ecologia da Maior Região de Florestas Tropicais, Editora Vozes: Petrópolis, 1985.

35. Silva, G. S.; Jardim, W. F; Fadini, P. S.; Sci. Total Environ. 2006, $368,189$.

36. Dorea, J. G.; Barbosa, A. C; Silva, G. S.; Comp. Biochem. Physiol., Part C: Toxicol. Pharmacol. 2006, 142, 275.

37. Bisinoti, M. C.; Júnior, J. L. B.; Malm, O.; Guimarães, J. R.; Jardim, W. F.; Quim. Nova 2006, 29, 1169.

38. Fadini, P. S.; Jardim, W. F.; Analyst 2000, 125, 549.

39. Dumarey, R.; Temmerman, E.; Dams, R.; Hoste, J.; Anal. Chim. Acta 1985, 170, 337.

40. Smith, K.; Gholz, H. L.; Oliveira, F. D.; Forest Ecol. Manag. 1998, 109, 209.

41. Rodrigues, W. A.; Furch, K.; Klinge, H.; AmazonianaLimnologia et Oecologia Regionalis Systemae Fluminis Amazonas 2001, 16, 441.

42. Roulet, M.; Lucotte, M.; Water, Air, Soil Pollut. 1995, 80, 1079.

43. Schluter, K.; Environ. Geology 2000, 39, 249.

44. Oliveira de, L. C.; Serudo, R. L.; Botero, W. G.; Mendonça, A. G. R.; Dos Santos, A.; Rocha, J. C.; Quim. Nova 2007, 30, 274.

45. Serudo, R. L.; Oliveira de, L. C.; Rocha, J. C.; Paterlini, W. C.; Rosa, A. H.; Silva da, H. C.; Botero, W. G.; Geoderma 2007, 138, 229.

46. Miretzky, P.; Bisinoti, M. C.; Jardim, W .F.; Chemosphere 2005, 60,1583 .

47. Silva, G. S.; PhD Thesis, Universidade Estadual de Campinas, Brazil, 2004.

48. Bisinoti, M. C.; Ph.D. Thesis, Universidade Estadual de Campinas, Brazil, 2005.

49. Silva, G. S.; Jardim, W. F.; Fadini, P. S.; J. Braz. Chem. Soc. 2009, in the press.

50. Brosset, C.; Water, Air, Soil Pollut. 1987, 34, 145.

51. Schroeder, W.; Lindqvist, O.; Munthe, J; Xiao, Z.; Sci. Total Environ. 1992, 125, 2366. 
52. Amyot, M.; Mierle, G.; Lean, D. R. S.; Mcqueen, D. J.; Environ. Sci. Technol. 1994, 28, 2366.

53. Zika, R. G.; Moffett, J. W.; Petasne, R. G.; Cooper, W. J.; Saltzman, E. S.; Geochim. Cosmochim. Acta. 1985, 49, 1173.

54. Cooper, W. J.; Lean, D. R. S.; Environ. Sci. Technol. 1988, 22, 1156.

55. Cooper, W.; Lean, D. R. S.; Environ. Sci. Technol. 1989, 23, 1425.

56. Amon, R. M. W.; Benner, R.; Geochim. Cosmochim. Acta 1996, 60, 1783.

57. Southworth, B. A.; Voelker, B. M.; Environ. Sci. Technol. 2003, 37, 1130.

58. Lalonde, J. D.; Amyot, A.; Orvoine, J.; Morel, F. M. M.; Auclair, J-C.; Ariya, P. A.; Environ. Sci. Technol. 2004, 38, 508.
59. Bisinoti, M. C.; Sargentini Junior, E.; Jardim, W. F.; J. Braz. Chem. Soc. 2007, 18, 544.

60. Sellers. P.; Kelly, C. A.; Rudd, J. W. M.; Machutchin, A. R.; Nature 1996, 380, 694.

61. Siciliano, S. D.; Lean, D. R.; Environ. Toxicol. Chem. 2002, 21, 1184.

62. Bisinoti, M. C.; Jardim, W. F.; RMZ-M\&G 2004, 51, 825.

63. Oliveira, L. C.; Sargentini Jr., E.; Rosa, A. H.; Rocha, J. C.; Simões, M. L.; Martin Neto, L.; Silva, W. T. L.; Serudo, R. L.; J. Braz. Chem. Soc. 2007, 18, 860.

Received: February 11, 2009

Web Release Date: June 26, 2009

FAPESP helped in meeting the publication costs of this article. 